\title{
Transaction Costs of the Striped Buffalo Market in the North Toraja Regency
}

\author{
A.Erna Sri Mustafa1, Arman', Sitti Nurani Sirajuddin², NurdwianaSari Saudi ${ }^{2}$ \\ ${ }^{1}$ Agribusiness Study Program, Faculty of Agriculture, Animal Husbandry and Fisheries Muhammadiyah University, Pare-pare \\ 2Socio-Economic Study Program, Faculty of Animal Husbandry, Hasanuddin University, Makassar \\ ${ }^{2}$ Economics Study Program, Faculty of Economics and Business, Hasanuddin University, Makassar
}

Correspondence Author: A.Erna Sri Mustafa. Agribusiness Study Program, Faculty of Agriculture, Animal Husbandry and Fisheries Muhammadiyah University, Pare-pare.

E-mail: Asyamshadiq@gmail.com

Received date: 29 August 2019, Accepted date: 01 October 2019, Online date: 30 October 2019

Copyright: (C) 2019 A.Erna Sri Mustafa. This is an open-access article distributed under the terms of the Creative Commons Attribution License, which permits unrestricted use, distribution, and reproduction in any medium, provided the original author and source are credited.

\begin{abstract}
The aim of this study is to (1) identify various transaction costs incurred by the farmers and (2) look at the effect of transaction costs from striped buffalo in the market. To achieve these objectives, qualitative and quantitative approaches are used with multiple linear regression analysis tools. The research was conducted from April to July 2019 in the North Toraja Regency by taking a sample of 30 breeders who specialized in selling striped buffalo. The results showed the largest transaction costs incurred by farmers was a brokerage fee of $\mathrm{Rp} .5,000,000 / \mathrm{buffalo} /$ transaction $(\mathbf{1 2 . 3 0 \%})$ and the least cost is the transportation fee of Rp. $2,100,000 / m o n t h(0.53 \%)$. The amount of the brokerage fee is due to the information gap from the lack of education and weak negotiating abilities. The results of the regression analysis showed that brokers significantly affected the market of striped buffalo with a sig value of 0.006 .
\end{abstract}

Keywords: transaction fees, striped buffalo, breeders, marketing

\section{INTRODUCTION}

The Toraja tribe is one of the community groups that develop the livestock sector through massive buffalo cultivation which can be achieved by meeting the needs of the community for buffalo cattle related to traditional rituals that had been carried on for generations. Based on the data from the North Toraja Regency Livestock Services, the number of buffalo cattle slaughtered in 2015 was 7,468, 2016 was 8,500 and 2017 was 8,573. From these numbers, 95\% of the slaughter was done for the needs of traditional parties and the rest through slaughterhouses [1]. Buffalo is an animal that has a high social value in Toraja because it symbolizes wealth and prosperity, the pride of its owner, a measure of community social life, and the main condition in the implementation of traditional customs. In general, buffalo in Toraja are divided according to several classes where each class influences the way the community views the social status of the owner.

a. Saleko buffalo (striped buffalo) has black stripes that are symmetrical. The sale value is a minimum of IDR.300,000,000 $1,000,000,000 /$ buffalo.

b. Bonga buffalo (also a striped buffalo) has colored stripes on most of its body but is less symmetrical. The selling value is between IDR.50,000,000 - IDR. 200,000,000/buffalo depending on the distribution ratio of the stripes on the body of a buffalo.

c. Pudu buffalo is generally stout and has a black body. The pudu buffalo is commonly used in tedong mappasilaga events because of its black, strong, and stocky body as a fighter buffalo. The more often the buffalo wins in battle events; the price will be more expensive. The selling value of this type of buffalo is between IDR 30,000,000 - IDR 100,000,000/buffalo.

d. Balian Buffalo is a neutered male buffalo. This buffalo is used only as a complement to the nobility who must have all types of buffalo in the ritual of the feast of death. The selling price is between IDR. 30,000,000 - IDR 70,000,000/buffalo.

e. Sambao buffalo has gray fur, gloomy colors, and a small body like a donkey. The sambao buffalo is usually called the servant buffalo and its value is the cheapest. The selling price is between IDR. 6,000,000-IDR. 10,000,000/buffalo.

f. Moon buffalo (albino buffalo) has all striped skin including its eyes. This buffalo is rarely used because it doesn't attract much interest. The selling price is IDR 1,000,000-IDR 3,000,000/buffalo [2]. 
The striped buffalo (saleko and bonga) has an important meaning in every death party ritual (rambu solo). Since it is young, the maintenance of the buffalo is rather time-consuming considering the price continues to rise which also increases pride and symbolizes the social size of the owner. The Toraja people believe the use of striped buffalo in the feast of death as a vehicle to be ridden by a dead spirit to bring it faster towards nirvana, while black buffalo and other buffaloes are as followers who smooth the way up to nirvana. The Toraja people also assess the price of buffalo based on the characteristics of the buffalo including eye color, model and color of the horn, tail condition, and fur swirls. [3][4].

Often the buffalo in the same class have different prices depending on the assessment of different characteristics [4].In the marketing of buffalo cattle, especially striped buffalo in the North Toraja Regency, several institutions play a role, such as wholesalers, collectors, retailers, and even consumers. At this institutional level, there are gaps related to market information and limitations in processing information resulting in transaction costs [5]. Transaction costs are categorized as costs incurred outside of production costs. The existence of these costs will increase the total costs incurred in the business. Transaction costs will make the difference in prices received by consumers and prices received by producers very far. [6] said that transaction costs are inevitable costs. Every exchange that occurs either the exchange of goods/services or information exchange will result in an exchange fee, namely transaction costs. In small-scale trade such as agricultural products in rural areas, the transaction costs are difficult to identify by the business actors themselves. [7] Argues that the low level of education of rural business actors results in the difficulty of business operators to distinguish or classify all forms of costs that will be or have been incurred. Difficulty in identification will reduce the profits that will be received by business actors because they have unconsciously spent on several other costs outside of production costs that are not considered and not previously allocated. [8] Defines transaction costs as the costs of negotiation, measuring and enforcing an agreement. [9] Transaction costs can be grouped into three categories, namely (1) search and information costs; (2) costs of negotiation, decision making, contract execution; (3) operational or monitoring costs. [10] Transaction costs can be separated into transaction costs before the contract (ex-ante) and after the contract (ex-post).

\section{RESEARCH METHODS}

\section{Research Location and Time}

The research was conducted from May to July 2019 at the Bolu Animal Market, North Toraja Regency, and South Sulawesi Province. The location selection was chosen purposively considering that this area is the center of buffalo cattle marketing especially striped buffalo to be used in socio-cultural activities within the community.

\section{Data Collection}

Data collection was done through primary data obtained through interviews using questionnaires, while secondary data was obtained through agencies related to the research such as the livestock service, regional revenue offices, village offices, and investment offices.

\section{Populations and Samples}

The population in this study were all breeders who sold striped buffalo in the North Toraja Regency. The sample in this study was 30 striped buffalo breeders who happened to be found in the North Toraja District.

\section{Data Analysis Method}

In this study, the data analysis used is multiple linear regressions to see the effect of various variables both partially and simultaneously on the marketing of buffalo striped cattle in the North Toraja Regency.

The shape of the regression model is:

$Y=\alpha+\beta_{1} X_{1}+\beta_{2} X_{2}+\beta_{3} X_{3}+\beta_{4} X_{4}+\beta_{5} X_{5}+\beta_{6} X_{6}$

where:

$\mathrm{Y}=$ striped buffalo market

$\mathrm{B}=$ intercept coefficient

$\mathrm{X}_{1}=$ transportation costs(IDR/month)

$\mathrm{X}_{2}=$ buffalo finder's fee (IDR/)

$\mathrm{X}_{3}=$ administrations fee (IDR/month)

$\mathrm{X}_{4}=$ broker's fees (IDR/time)

$\mathrm{X}_{5}=$ consumables fees (IDR/month)

$\mathrm{X}_{6}=$ informational fees(IDR/month)

\section{RESULTS AND DISCUSSION}

\section{A. Transaction Costs in the Marketing of Buffalo}

Transaction costs incurred by farmers include costs from the procurement of inputs to the marketing of livestock. These costs can be calculated per month but there are also those calculated per transaction considering the transaction is uncertain. Transaction costs incurred by farmers include:

\section{The cost of finding a buffalo}


Citation: A.Erna Sri Mustafa et al, 2019. Transaction Costs of the Striped Buffalo Market in the North Toraja Regency. Advances in Environmental Biology., 13(10): 31-35.DOI:10.22587/aeb.2019.13.10.4

These costs are incurred by farmers when searching for buffalo to the countryside or outside the city following the information they receive from farmers or brokers. These costs adjust depending on the area they visit. In this activity, the costs incurred in the form of transportation costs, consumption, cigarettes, brokers, and renting trucks to transport buffalo with an agreed price. The stages are that farmers get information about the existence of buffalo, see buffalo photos and get an initial offer of buffalo prices from farmers in the destination village. If they are interested, they will immediately come to the location to check the characteristics of the buffalo and bring the buffalo home if the offer price has been agreed upon by the two parties.

\section{Administration fee (entrance ticket)}

This fee is paid when entering the buffalo market on a market day which takes place twice a week, Tuesday and Saturday. The price of admission tickets per buffalo is 10,000/buffalo/market day. If they bring more than 5 animals, there will usually be a ticket discount.

\section{Broker's fees}

These costs are incurred by farmers or consumers who need information about the existence of the buffalo they want or people who help farmers sell their buffalo. For Torajan people, they are called pembongkaran. These brokers will usually actively go around meeting farmers and asking about their buffalo selling prices and looking for buyers. Brokers usually benefit from the cost of sales services or take the difference from the buffalo selling price.

\section{Consumables fees}

These costs are incurred by farmers to pay for food, drinks, and cigarettes when they come to sell their buffalo at the bolu market. Generally, the costs incurred are 50 thousand/market day.

\section{Information costs}

These fees are in the form of pulse fees and casual costs in the public areas to get information about buffalo price developments and consumers who need striped buffalo.

\section{Transportation costs}

These costs are in the form of daily gasoline purchases or truck rental costs incurred by farmers from their homes to the bolu market, which is calculated in a month.

Table 1: Data on average transaction costs of 30 farmers in the marketing of buffalo striped in the North Toraja Regency

\begin{tabular}{|c|c|c|c|c|c|}
\hline \multirow{2}{*}{ Types of Transaction Fees } & Min Value & $\%$ & Max Value & $\%$ & Average \\
\cline { 2 - 6 } & (IDR/month) & & (IDR/month) & & (IDR/month) \\
\hline Finder's Fee & 50,000 & 0,15 & $3,000,000$ & 9,23 & $1,082,500$ \\
\hline Entrance Fee & 10.000 & 0,89 & 300.000 & 26,78 & 37,333 \\
\hline Broker's Fee & 200.000 & 0,74 & 5.000 .000 & 12,30 & 1.355 .000 \\
\hline Consumables Fees & 70.000 & 1,70 & 250.000 & 6,09 & 136.833 \\
\hline Information Fees & 100.000 & 1,69 & 350.000 & 5,91 & 197.333 \\
\hline Transportation Fees & 100.000 & 11,08 & 2.100 .000 & 0,53 & 631.667 \\
\hline
\end{tabular}

Source: Primary data that has been processed, 2019

Table 1 shows one of the biggest transaction costs incurred by farmers which are the broker's fee with the highest value of IDR. $5,000,000 /$ buffalo/transaction or $12.30 \%$. The value of this fee can be big or small depending on the broker's ability to sell striped buffalo. Usually, brokers will increase their service costs above the buffalo selling price to consumers, the better the characteristics, the selling prices will be high and the broker's service costs will also be large. The broker takes advantage of the shortage of farmers who still use simple telecommunications tools and limited education in finding information about buffalo sales. The advantage of a broker is being able to capture information quickly through a wide network of friends and good negotiating skills. This is consistent with the opinion of [7] that at the institutional level, there are gaps related to market information and limitations in processing information leading to extra transaction costs. Transaction costs will make the difference in prices for the consumers and funds received by the producers. Active brokers can find out where the location of farmers who have striped buffalo even in remote villages so they can direct customers to look for it adding substantial service costs.

The second-largest transaction cost is the cost of finding a buffalo with the largest value of Rp. 3,000,000/buffalo or 9.23\%. These costs are usually incurred by farmers who are willing to take the risk to spend more capital to find a quality buffalo to go outside the city such as NTT Province, Mamasa Regency, Palopo City, Jeneponto Regency, or Bone Regency. [11] Buffaloes for traditional festivals at this time are taking from outside North Toraja due to the lack of quality feed, the application of technology that is not intensive enough so that buffalo productivity is low and not yet optimal for the integration of livestock and crops to produce quality feed. Well-characterized buffalo has an appropriate navel (palisu) position, symmetrical stripes, and a good horn model. When it is the party season, striped buffalo will be sold at a price that is quite fantastic reaching hundreds of millions per buffalo. Clever breeders will usually try to mate striped buffalo with fellow striped buffalo or black buffalo to be able to produce striped buffalo considering the potential birth of striped buffalo is very difficult.

The smallest transaction cost incurred by farmers is transportation costs. Many buffalo breeders in North Toraja choose to come to the bolu market on foot with their buffalo. Alongside the roads in the morning and evening, farmers will graze their buffalo toward the river to be bathed. Meanwhile, farmers who come from remote areas go to the bolu market by renting a pick-up car or 
truck to transport the buffalo. Transportation costs range from IDR. 300,000 - IDR500,000 round trip depending on the distance. There are quite a lot of trucks or pickups used as buffalo transport cars in Toraja, because besides being used to transport buffalo, also to pick up a lot of grass feed or transport people from the countryside when visiting parties.

\section{B. Analysis Results from the Breeders Data Regression Test in Marketing of the Striped Buffalo in the North Toraja Regency.}

Analysis of the data used in this study is multiple linear regression analysis. This analysis is used to see some of the variables that most influence the striped buffalo market [12]

Table 2: Breeders Regression Test Results in the Marketing of the Striped Buffalo in the North Toraja Regency.

\begin{tabular}{|c|c|}
\hline \multirow{2}{*}{ Tests } & Sig \\
\cline { 2 - 2 } & Breeder \\
\hline Looking for a Buffalo & .345 \\
\hline Administration/Entrance Fee & .561 \\
\hline Brokers & .006 \\
\hline Consumables & .773 \\
\hline Information & .845 \\
\hline Transportation & .941 \\
\hline $\mathrm{R}$ & .596 \\
\hline $\mathrm{R}^{2}$ & .356 \\
\hline F Test &, 91 \\
\hline
\end{tabular}

Source: Primary data that has been processed, 2019

Table 2 shows the results of data processing using the SPSS program bringing to a conclusion that the regression equation obtained:

$$
Y=113810864,112+19,649 X_{1}-241,845 X_{2}+52,926 X_{3}-141,864 X_{4}+67,685 X_{5}-2,710 X_{6}+0,05(e)
$$

1. The value of the variable looking for buffalo $(\mathrm{X} 1)$ of $+19,649$ with a significance value of 0.345 . A positive value indicates that the variable looking for buffalo has a direct relationship but does not have a significant (significant) effect on Y. It means that even if farmers increase or decrease the variable looking for buffalo by one unit, it will not affect the marketing of striped buffalo.

2. The value of the entrance ticket variable (X2) of -241.845 with a significance value of 0.561 . A negative value indicates that the addition or reduction of one unit of this variable, does not affect the value of Y (striped buffalo marketing) becau se statistically, this variable has no significant effect.

3. The value of the broker variable $(\mathrm{X} 3)$ of $+52,926$ shows that this variable is in line and significantly influences the $\mathrm{Y}$ variable (striped buffalo marketing) with a significance value of 0.006 .

4. The value of the consumption variable (X4) of - 141.86 with a significance value of 0.773 indicates that the addition or subtraction of one unit of this variable, does not affect the value of $\mathrm{Y}$, because the value is negative and not significant.

5. The value of the information variable $(\mathrm{X} 5)$ is +67.668 with a significance value of 0.845 , indicating that this variable is in line but has no significant effect on the $\mathrm{Y}$ variable.

6. The value of the transportation variable (X6) is - 2.710 with a significance value of 0.941 , indicating that this variable does not affect the $\mathrm{Y}$ variable because the value is negative and not significant.

The coefficient of determination shown by R2 will give an idea of how much influence all the independent variables together have on the dependent variable (Y). Based on table 2 , the value of R square (R2) is 0.356 where all independent variables used in this study affect the dependent variable by $3.56 \%$ and the remaining $64.4 \%$ is influenced by other variables outside this study such as buffalo characteristics and buffalo types.

\section{CONCLUSION}

1. Farmer transaction costs incurred in marketing striped buffalo cattle are the costs of finding buffalo, administration, broker fees, transportation, communication, and information.

2. One of the biggest transaction costs is a broker fee of $12.30 \%$ while the smallest transaction fee is a transportation fee of $0.53 \%$.

3. From the results of the multiple regression analysis, the significant variable is the broker fee with a value of 0.006 .

4. Due to the gaps in information, education, friendship networks, and weak breeders in negotiating, these opportunities are taken up by brokers.

\section{SUGGESTIONS}

More optimal support from the local government related to the management of the buffalo cattle business from upstream to downstream considering the livestock sector is closely related to the tourism sector which is the largest source of income for the Toraja Regency.The need for counseling and guidance for buffalo breeders to increase buffalo livestock production in the region of the North Toraja Regency considering the buffalo level is high enough so that it does not depend on supply from other 
regions. Adding facilities such as buffalo cages and clean water facilities so that the market looks clean and comfortable so that visiting tourists feel comfortable.

\section{ACKNOWLEDGEMENTS}

Acknowledgments to the researchers in RISTEKDIKTI for the assistance of the Higher Education Collaboration Research Grant (PEKERTI) so that we can research on several issues related to Buffalo Cattle in the North Toraja Regency. Also, we would like to say thanks to the Regional Government of the North Toraja Regency through the investment service, livestock service office, and regional revenue service for their assistance and cooperation. Finally, a thank you to the TPM Partners from Hasanuddin University for their support and good cooperation.

\section{REFFERENCES}

[1] North Toraja Regency Livestock Services. 2018. Population Data for Large Cattle and Buffalo Cattle Slaughterings in North Toraja Regency. Toraja Utara.

[2] Mustafa, S.E.A. 2012. Demand for Buffalo (Bubalus Bubalis) in Sa'dan District, North Toraja Regency. [Thesis]. Graduate program. Hasanuddin University. Makassar.

[3] Sariubang M, et all. 2010. The Role of Buffalo in Toraja's Indigenous Community of South Sulawesi. Journal of the National Seminar on Animal Husbandry and Veterinary Technology. Institute for Agricultural Technology Study. Makassar.

[4] Asnawi. A and Saleh, I.M. 2013. Determination of the sale price of Striped Buffalo based on its characteristics in the Bolu Animal Market, North Toraja Regency. Faculty of Animal Science, Hasanuddin University. Makassar.

[5] S.N. Sirajuddin, et al. 2009. Effect of Transaction Costs on the Dairy Cattle Business System in the South Sulawesi Province. Faculty of Animal Science, Hasanuddin University. Makassar.

[6] Coase RH. 1937. The Nature of the firm. Economica

[7] Baye MR. 2010. Managerial Economics and Business Strategy. New York (US) : Mc Graw Hill Companies Inc.

[8] Yustika A.E. 2006. Institutional Economics. Definition, Theory and Strategy. Malang. Banyumedia Publishing.

[9] Mburu J. 2002. Collaborative Management of Wildwife in Kenya : An Empirical Analysis of Stakeholders Participation, cost and intensives. Socioeconomic studies on rural development

[10] Sumantyo R. 2014. Integrated Service System: Transaction Cost Perspective, Its Impact On Increased Investment in Klaten Regency. Journal Of Rural and Development Volume V No. 1 Februari. 2014. Universitas Sebelas Maret. Surakarta.

[11] Suarda A, et all. 2017. The Characteristics Of integration System of Buffalo Cultivation in North Toraja Regency. American Eurasian Journal Of Sustanaible Agriculture Vol (11) issue (1) pages (6-10). Makassar.

[12] Awalia, A.M. 2019. Factors That Affect Satisfaction of Service Users (Butcher) in Taccorong Slaughterhouse (SLP) of Bulukumba Regency. Thesis. Faculty of Agriculture, Animal Husbandry and Fisheries. Muhammadiyah Parepare University. Parepare. 